\title{
Islamic Banking and Green Banking for Sustainable Development: Evidence from Bangladesh
}

\author{
Mohammad Nazim Uddin ${ }^{1}$, Monir Ahmmed ${ }^{2}$
}

\begin{abstract}
Green banking is an integral part of Islamic banking that makes a basis of environmental protection. This study attempts to examine the relationship between Islamic banking and green banking that contribute to sustainable development. The study has used the primary data through a structural questionnaire that includes various dimensions on green banking of Islamic banking in Bangladesh. The investigation revealed that Islamic banks had made a significant contribution to green banking that improves the environment as means of cost and energy savings, preservation of natural resources and the need to respect all living things. The study seems to carry an enormous academic value since a few studies have undertaken in this area.
\end{abstract}

Keywords: green banking, sustainable development, Islamic banking.

\begin{abstract}
Abstrak. Perbankan ramah lingkungan merupakan bagian integral dari perbankan syariah yang menjadi basis perlindungan lingkungan. Studi ini mencoba untuk menguji hubungan antara perbankan syariah dan perbankan ramah lingkungan yang berkontribusi terhadap pembangunan berkelanjutan. Penelitian ini menggunakan data primer melalui kuesioner struktural yang mencakup berbagai dimensi tentang perbankan berbasis perbankan syariah di Bangladesh. Studi tersebut mengungkapkan bahwa bank syariah telah memberikan kontribusi signifikan terhadap green banking yang memperbaiki lingkungan sebagai sarana penghematan biaya dan energi, pelestarian sumber daya alam dan kebutuhan untuk menghormati semua makhluk hidup. Studi ini tampaknya membawa nilai akademis yang sangat besar karena beberapa penelitian telah dilakukan di bidang ini.
\end{abstract}

Kata kunci: perbankan ramah lingkungan, pembangunan berkelanjutan, perbankan syariah

\section{How to Cite:}

Uddin, M.N., \& M. Ahmmed. (2018). Islamic Banking and Green Banking for Sustainable Development: Evidence from Bangladesh. Al-Iqtishad: Jurnal Ilmu Ekonomi Syariah (Journal of Islamic Economics). Vol. 10 (1): 97 - 114. doi: http//dx.doi.org/10.15408/aiq.v10i1.4563 


\section{Introduction}

Climate change has the adverse effect on the environment that distresses the agriculture, forestry, water resources and human health. This issue has been turned into a global concern to protect the environment from any detrimental effect for sustainable development. In these circumstances, Islamic banking can play a supportive role in improving the environment for sustainable development. Islamic banking is an ethical and socially responsible banking which has no adverse effect on the environment. This banking dedicated to human being and society. It has high potentials to contribute towards sustainable financing ecosystem for the green world. Islam primarily promotes the preservation of natural resources and the need to respect all living things regarding the relationship between humankind and the environment. Imam Bukhari on renewable source of reward states-"If a Muslim plants a tree or sows seeds, and then a bird, or a person or an animal eats from it, it is regarded as a charitable gift (sadaqah) for him." Failure to do so would be detrimental, as stated in verse (Sura-Rum: 41) where the severe destruction of the land and sea would come upon those who mistreat the environment (Nor and Uddin, 2012). 'Shari' ah' is the moral code of Islamic law that provides the legal framework for regulation of many aspects of private and public life (Uddin, 2016).

Green banking plays a caring role for sustainable development in overcoming the institutional obstacles and market challenges, in the way to allocating the investment to the green projects. Green banking involves with banks strategic and operating plan. The plan takes into consideration the transition towards a lowcarbon economy and those internal controls, risk management and the projected financial condition based on proper assessment of environmental risks. Going green is indispensable for banks as the quality of assets and profitability; both depend upon the environmental and ecological aspects. This aspect takes care of the corporate social responsibility and is the ecological balanced approach that banks should follow. Green banking thus involves a two-pronged approach. Firstly, green banking focuses on the green transformation of internal operations of all banks. It means all the banks should adopt appropriate ways of utilizing renewable energy, automation and other measures to minimize carbon footprint from banking activities. Secondly, all banks should take environmentally responsible financing; weighing up environmental risks of the project, before making financing decisions; and in particular, supporting and fostering the growth of upcoming 'green' initiatives and projects. It is a smart and proactive way of thinking with a vision of future sustainability. Although, banking never considered as a polluting industry. The present scale of banking operations have considerably increased the carbon footprint of banks due to their massive use of 
energy (e.g., lighting, air conditioning, electronic/electrical equipment's, IT, etc.), high paper wastage, lack of green buildings, etc.

Therefore, banks should adopt technology, process, and products, which result in substantial reduction of their carbon footprint as well as develop a sustainable business. The paper discusses some of the main environmental challenges and risks to the banking sector and how can green banking be used to overcome these obstacles. The article also explores the ground of green banking from the practices of Islamic banking through the sufficient evidence of holy Quran and Hadith.

The issue of green banking has been a subject of significant concern for researchers and scholars in recent years. Such interest has carried about a lot of arguments on the subject, which led to numerous studies on it in the area of green banking over the years. The empirical researchers have provided mixed results between green banking and profitability for sustainable development. The present research has been done to determine the relationship between Islamic banking and green banking for sustainable development in developing countries and to examine the perception of managers and investors of sample banks. To establish the impact and clear understanding of the relationship between Islamic banking and green banking for sustainable development of a bank, the study has been undertaken by the researcher. These issues and the global debate on the nexus between green banking of Islamic banks and sustainable development raise two central questions. First, what is the relationship between Islamic banking and green banking will support the sustainable development of the bank? Second, under what state of affair is 'Shari'ah' compliance products consistent with green banking products? To answer these questions, the study undertaken.

This study explores why environmental sustainability is pertinent to green banking policy and regulation and shows how Islamic banks are using green banking products to meet sustainability challenges through internal bank operations and financial policy approaches that reflect their unique economic circumstances. The study suggests that Islamic banks have still further to go in using banking policy to promote the mobilization of green capital for investment and for mainstreaming environmental sustainability challenges into bank business strategies, governance, and regulatory practices. In this way, Green banking policy can more effectively support the economy's adaptation and transition to a more environmentally sustainable path. The paper is targeted to examine the 'Shari'ah' compliance products that reflect the green banking in operations and financing to support the sustainability of banks. The green banking helps the managers and bankers to control the actions at low-cost that enhance the profitability of the bank. The findings of the 
study would be useful to the policymakers and regulators and academician to show why environmental challenges are relevant to banking policy.

\section{Literature Review}

The study discovers the relationship between Islamic banking and green banking in Bangladesh. Most of the previous researchers have conducted on the aspects of Green Banking practices in Bangladesh. A few studies were done on the relationship between Islamic banking and Green banking for sustainable development in Bangladesh. The research would contribute to the development of existing literature and covers the literature gaps. Jaman, et al. (2016) analyzes the bankers' perceptions of the green banking concept, its benefits, its complexities of execution, and its possible relationship with Islamic banking. This research is an empirical study of 48 Islamic bankers from 21 branches of seven Islamic banks located in Dhaka, Bangladesh employing structured questionnaires. The analysis revealed that several bankers perceived green banking as an environmental banking that helped to protect the environment despite its high adoption cost. Also, green banking and Islamic banking were viewed to be compatible and interlinked as Islam supports resource savings, cleanliness, ethics and social responsibility all of which are also the mottos of Green Banking.

Islam \& Das (2013) stated that Green Banking is a new way of conducting the banking business through considering the hygienic environmental issue as well as corporate social responsibility (CSR). Nowadays, it is inevitable to practice green banking by banks because of globalization and to face the competition. The study concludes that green-banking practices in Bangladesh are not satisfactory at all. Millat et al. (2012) reported Bangladesh Bank had instructed all scheduled banks to formulate comprehensive policies for green lending and investment after rigorous and adequate analysis of environmental risks incorporating national environmental rules and acts. Uddin (2016) focused on the relationship between Islamic banking and green financing in Bangladesh. The study provides the evidence that the factors of green funding in Islamic banks are significantly following, but the amount of green financing is not sufficient relative to total financing. Most of the respondents are satisfied with the current green financing and green banking. Ullah (2012) studied on a very small sample of 4 banks. She observes that state-owned banks demonstrate nearly zero compliance with the GBG, continue to finance harmful projects, and have achieved little in introducing paperless banking while private banks have better agreement. Goyal \& Joshi (2011) highlighted social and ethical issues such as social Banking, ethical Banking, green Banking and rural banking which facilitate the achievement of sustainable development of banking and finance. 
They concluded that banks could act as a socially and ethically oriented organization by disbursement of the loan only to those organizations, which have environmental concerns. Rahman \& Barua (2016) finds that performance of banks in Bangladesh GBG implementation is not very satisfactory.

Chaurasia (2014) studied on Green Banking practices in Indian Banks. The study found that there has not been many initiatives to practice the green banking in India. The study suggested that bank should go green and play a proactive role to take ecological aspects as part of their lending principle, which would force industries to go for mandated investment for environmental management, use of appropriate technologies and management systems. Green banking requires that the financial institutions should encourage projects which take care. First, sustainable development and use of natural renewable natural resources; Second, protection of human health, biodiversity, efficient production and use of energy, and; Third, pollution prevention and waste minimization, pollution controls (Biswas, 2011). Choudhury et al. (2014) encouraged the necessity of stakeholder's influences in green banking practice and recommends some indication for Government, the whole banking sector and for the business community. This literature review attempts to identify the gap in this study and improves this difference for the development of research. Shaumya and Arulrajah (2017) found that the green banking practices have the positive impact on bank's environmental performance.

Islamic banks involve in Islamic banking activities based on profit and loss sharing (PLS) system, rather than interest. These banks are socially responsible while providing finance and are monitored by expert bankers side by side guided by the 'Shariah' (Islamic law) Board. Islamic banks do not lend money to the tobacco industry, gambling industry, production of goods that damage physical or mental health or harmful to the environment or any product or service industry involve in unethical practices. These practices have proximity to the SRI (Socially Responsible Investment) of the western world. Islamic Bank is committed to establishing a socio-economic justice system where the public interest and social welfare give precedence over parochial individual interests. Islamic banks do not work to meet the illegitimate demands of insignificant number greedy people. These entities do not give priority only to financial gain and ignore other socioeconomic problems. The Bank aims to run in such a way that it doesn't have any negative impact either on society or the environment. The principles of the Bank based on 'Shari' ah' have a direct impact on how it invests and utilizes its resources. It does not finance enterprises that deal in morally questionable businesses like investments in tobacco, liquor, etc. The Bank attempts to maximize social welfare, reduce hazards, and protect the nature and any degradation in its operational areas 
and activities. Moreover, the Bank's core principle is the protection of resources for the future generation.

Islamic banking is green Banking. Green banking avoids paperwork to the optimum level and focuses on electronic transactions like the use of ATM, mobile banking, online banking, etc. for various banking transactions by the customers. Electronic transaction not only aids towards sustainability but also provides convenience to the customers as well as to the banks. Less paperwork means less cutting of trees. For implementing eco-friendly business, banks should adopt environmental standards of lending as it improves the asset quality of the banks (Tara et al., 2015). Islamic banks have no chance of participating in grey investments. It's a moral obligation for Islamic banks to adopt environment protection process in their every investment. Under the green banking activities, Islamic banks have ensured fuel-efficient electrical equipment, usage of solar panel, hundred percent online dependent internal communications. The green banking recognizes the environmental hazards caused by consumption of resources and release of waste from own business activities and aims to protect the environment through resource re-using and recycling as well as efficient use of energy and resources. Green banking aims to continually minimize the operational environmental impacts by monitoring environmental performance; setting improvement targets; and by implementing and evaluating environmental management program that saves energy and water, manages wastes, recycle materials, reduce business trips, and promote green procurement and provide a full range of e-banking services. The Bank adopts processes to assess the environmental and social risks and opportunities arising from its client's business activities and manages the Bank's exposure to reduce its carbon footprint on the environment according to Environmental Conservation Rules (ECR) 1997 and Environmental Risk Management (ERM).

The study attempted to recognize the relationship between green banking as the source of Islamic banking and sustainable development. Sustainable Development is the way of using the resources that not only meet the human needs of present and future generation but also preserve the environment (United Nations, 1987). Sustainable development aims at providing the economic advancement and progress while protecting the long-term value of the environment. It provides a framework for the integration of environmental policies and development strategies (United Nations General Assembly, 1987). The field of sustainable development comprises of three constituents: environmental sustainability, economic sustainability, and socio-economic sustainability. Sustainable banking as per the United Nations Environment Programme Finance Initiative (UNEP-FI, 2007) defined as "the process by which the banks consider the impact of their various operational 
activities and their products and services for meeting the needs of the current as well as the future generations." The green banking plays a pioneering role in the era of banking to meet the objectives of sustainable development. The definition of Islamic banking, green banking and sustainable development provide a clear understanding of developing the framework of their integrated relationship. The goal of sustainable development would not attain without using the Islamic based banking. The Islamic banking provides a moral obligation to practice the green banking in the modern banking world.

Hypotheses: The below hypothesis have suggested based on the theoretical framework and research objectives:

$H_{01}$ : There is a significant relationship between Islamic banking and green banking.

$H_{01}$ : There is a significant relationship between Islamic banking and sustainable development.

$H_{01}$ : There is a significant relationship between green banking and sustainable development.

\section{Method}

The study is qualitative research and based on both primary and secondary data. Primary data have collected through questionnaire method. The target populations of this study are investors, executives, and managers of Islamic banks in Bangladesh. There are full-fledged eight Islamic banks in Bangladesh namely; Islami Bank Bangladesh Limited, Al-Arafa Islami Bank Limited, Social Islami Bank Limited, Exim. Bank Limited, Shahjalal Islami Bank Limited, First Security Islami Bank Limited, ICB Islami Bank Limited, and Union Bank Limited. The union bank has not been taken into consideration as sample due to newly established in 2013. The study has made six branches of each bank from 7 Islamic banks located in Chittagong and Dhaka. The main reason for selecting two districts are capital districts and convenient to researcher himself. The total sample is 126 respondents of which 42 bank officials and 84 investors selected for interviewing from 42 branches of 7 Islamic banks in Chittagong and Dhaka equally.

It was decided to allocate one questionnaire to each official of each branch, and two questionnaires were given two customers of each branch of selected samples. Given the limited resources and time at the disposal, all the branches and all investors could not investigate. Secondary data and information relevant to this study have collected from available publications including journals, articles, the website of Bangladesh bank, Studies conducted by various donor and development agencies such as UNDP, Environmental organizations, World Bank, and NGOs. Data and 
information thus collected have been processed manually as well as through a personal computer. Descriptive statistics such as 5-point Likert scale, average, and percentage, have been used in this study to analyze the data for the validity of findings. The results of the survey have been analyzed critically to make the review more informative, useful and acceptable to the readers, academicians, policymakers, and those people who are devoted to protect the environment and develop the friendly environment in developing countries as well Bangladesh as a whole.

\section{Result and Discussion}

The study has been directed to examine the relationship between Islamic banking and green banking for sustainable development. The study tries to explore the views of management of Islamic banks towards green banking in Bangladesh. Islam pressures on the necessity and significance of environmental protection, i.e., living in harmony with nature, achieving sustainable development, enriching life on earth, and making the best use of available resources (Jaman et al., 2016). In the Quran, it is declared that Men are the superior living being, Asraful Makhlukat, (Surah Bani Israil, 17:70, Surah al-Baqarah, 2:29 \& Surah Jathiyah, 45:13) in the planet and have endowed with a sense of moral insight (Surah ash-Shams, 91:7 - 8). Their relationship to the earth is seen as that of custodian (Surah Hud, 11:61) (Mutahhari, 2014). The message of Islam is that the relationship between the Allah and men is as significant as the care of the environment and natural resources. Therefore, the perception of management of 'Shari'ah' based banks about green banking has analyzed as follows.

Table 1. Demographic Information of the of the Respondent

\begin{tabular}{llcc}
\hline \multirow{2}{*}{ Gender } & & Frequency & Percentage \\
& Male & 35 & $83 \%$ \\
Age & Female & 7 & $17 \%$ \\
& Below -30 & 6 & $14 \%$ \\
\multirow{3}{*}{ Marital Status } & $30-45$ & 28 & $67 \%$ \\
& $45-60$ & 8 & $19 \%$ \\
Education & Single & 9 & $21 \%$ \\
\multirow{2}{*}{ Designation } & Married & 33 & $79 \%$ \\
& Graduation & 0 & $0 \%$ \\
& Post-graduation & 42 & $100 \%$ \\
\hline
\end{tabular}

Source: Field investigation 
In the questionnaire, there is a section concerning demographic profile to attain the information reliability of the study. The demographic information is related to the respondents' gender, age, marital status, education and other factors might influence their perception. The demographic data has presented the form of Table 1. Table 1 indicates that 83 percent of the respondents were male and 17 percent of the respondents are female in the study. Out of the total respondents, 14 percent of the respondents were below 30, 67 percent of respondents were between 30 and 45 and 19 percent of respondents were between 45 and 60 years range. 21 percent of respondents were single, while married accounted for 79 percent. A large number of percentage (76\%) were executive level followed, maximum of them were the top executive and remaining of the respondents are branch level managers.

This question consisting of 8 sub-questions designed to test the green banking environment of Islamic banking. These issues have been presented to the respondents to explore their opinion about the components of green banking environment in Islamic banking. The green banking preparation of Islamic banking presents in Table 2.

Table 2. Pre-conditions of green banking environment in Islamic banks

\begin{tabular}{lcc}
\hline \multicolumn{1}{c}{ Queries } & \multicolumn{2}{c}{ Response } \\
\hline The bank has a separate green banking cell & $100 \%$ & No \\
Do you have the knowledge of green banking & $92 \%$ & $0 \%$ \\
Have you participated training program on green banking & $95 \%$ & $8 \%$ \\
Your bank arranges green awareness program & $82 \%$ & $05 \%$ \\
The bank having any fund only for green banking & $78 \%$ & $18 \%$ \\
The bank has any climate change risk fund & $62 \%$ & $22 \%$ \\
Is there any conflict between green banking and Islamic banking & $100 \%$ & $38 \%$ \\
\hline
\end{tabular}

Source: Field investigation.

The study has examined the scenario of green banking in Islamic banks of Bangladesh. Most of the Islamic banks have developed green banking environment within internal and external premises of the banks. The respondents provided an opinion that their banks separate green banking cell, awareness programs, training programs, green banking fund, and risk fund. They also answered that there is no conflict between Islamic banks and green banking. Islamic banking is a green banking. Finally, it can be concluded that shari'ah based banks have good green banking environment in Bangladesh. 
All participated respondents felt that green banking philosophy is very conducive to the 'Shari'ah' compliance. Green banking as a part of Islamic banking was highly correlated with each other.

Table 3. Relationship between Green banking and Islamic banking

\begin{tabular}{ccc}
\hline Statement & \multicolumn{2}{c}{ Response } \\
& Yes & No \\
\hline Does green banking philosophy is conducive for shari'ah compliance? & $100 \%$ & $0 \%$ \\
\hline
\end{tabular}

Source: Field Investigation

The study has been conducted on the views of managers to examine the practices of green banking in house. The result of survey has been highlighted in the Table 4.

Table 4. Green banking practices in Islamic banks

\begin{tabular}{lcccccccc}
\hline \multicolumn{1}{c}{ Statements } & $\mathbf{1}$ & $\mathbf{2}$ & $\mathbf{3}$ & $\mathbf{4}$ & $\mathbf{5}$ & Total & Mean & Rank \\
\hline Green office guide & 60 & 60 & 21 & 16 & 157 & 3.74 & 9 \\
$\begin{array}{l}\text { Green training and awareness } \\
\text { program }\end{array}$ & 100 & 60 & 21 & & 181 & 4.31 & 5 \\
E-banking in operational activities & 150 & 40 & 6 & & 196 & 4.67 & 1 \\
On-line banking in operational & 125 & 40 & 21 & & 186 & 4.43 & 2 \\
activities & 50 & 60 & 24 & 18 & & 152 & 3.62 & 10 \\
On-line advertisement & 90 & 56 & 18 & & 4 & 168 & 4.00 & 7 \\
Waste management & 110 & 60 & 15 & & & 185 & 4.41 & 3 \\
Energy \& water savings & 105 & 64 & 9 & 4 & & 182 & 4.33 & 4 \\
Paper consumption & 85 & 72 & 21 & & 178 & 4.24 & 6 \\
Renewable energy savings & 60 & 64 & 42 & & 166 & 3.95 & 8 \\
Green travel & & & & & &
\end{tabular}

Source: Field investigation

Table 4 indicates the priority of green banking practices in the house of Islamic banking. Respondents of the study felt that they are using e-banking in operational activities of office management within the bank which is ranked by 01 . The most of respondents agreed that they have connected with online banking in their banking operations that are rated by 03 . The respondents also revealed that they are very 
conscious in saving the water and energy in the premises of banking activities, which ranked as 03 . A significant number of respondents reported that they are working in the office with paper consumption, which is listed 04 . The respondents opined that the banks had arranged some green training and awareness programs to perform the green work in the premises of bank that is ranked by 05 . The Islamic banks are using renewable energy savings to operate the banks at minimum cost that is rated 06. The respondents stated that demand management, reuse, and recycling are the indicative methods of reducing solid waste, which ranked as 07 . Reporting from the respondents that Islamic banks always encourage the officials to choose green approaches for any business travel, which reduce environmental impact, which is ranked by 08. A good number of respondents stated that Islamic banks routinely provide green office guide to take care of green banking that classified as 09 . Some respondents recommended that they give the online based advertise because of cost savings and area coverage. The mean score of all components of green banking is higher than 3.0, which means the usage of green banking in Islamic banking.

The study investigates the practices of components of green banking by reconnoitering the views of bankers. Most of the bankers do believe that green banking is the Islamic banking and other parts are the associate of green banking. Though green banking (environment-friendly banking, ethical banking or sustainable banking) can defined in some ways, in a broader perspective, it is the environment-friendly banking practices that promote their customers to reduce the carbon footprint through their banking activities (Tara et al., 2015). The opinions of bankers are highlighted herewith in Table 5.

Table 5. Management perception on the usage of components of Green banking in Islamic banking

\begin{tabular}{lcccccccc}
\hline \multicolumn{1}{c}{ Statements } & $\mathbf{1}$ & $\mathbf{2}$ & $\mathbf{3}$ & $\mathbf{4}$ & $\mathbf{5}$ & Total & Mean & Rank \\
\hline Environmental friendly banking & 120 & 60 & 9 & & 189 & 4.50 & 1 \\
Sustainable banking & 105 & 64 & 15 & & 184 & 4.38 & 3.5 \\
Social responsible banking & 100 & 64 & 18 & & 182 & 4.33 & 5 \\
Ethical banking & 95 & 80 & 9 & & 184 & 4.38 & 3.5 \\
Economy banking & 95 & 84 & 6 & & 185 & 4.40 & 2 \\
\hline
\end{tabular}

Source: Field investigation

Table 5 describes the management perception of practices of components of green banking in Islamic banks. The most of respondents reported that they do 
practice the environmental banking, economy banking, sustainable banking, ethical banking and social responsibility banking in their operations. The score of green components highly correlated with each other. It is clear that Islamic banking is green and sustainable banking, which also tested from the previous study. Green banking defined as Shariah-based banking and sustainable banking in a very cheap manner (Masukujjaman, et al., 2016).

The following factors have to be considered before making the investment decision. These factors will develop green investment climate. The study tries to identify the views of management concerning the green factors of investment. The opinions of management have inserted in Table 6.

Table 6. Management perception towards investment climate before investment decision

\begin{tabular}{lcccccccc}
\hline \multicolumn{1}{c}{ Statements } & $\mathbf{1}$ & $\mathbf{2}$ & $\mathbf{3}$ & $\mathbf{4}$ & $\mathbf{5}$ & Total & Mean & Rank \\
\hline $\begin{array}{l}\text { Cleaning and hygienic business } \\
\text { environment }\end{array}$ & 105 & 68 & 9 & 2 & & 184 & 4.38 & 4 \\
Green factory buildings & 110 & 56 & 12 & 4 & 182 & 4.33 & 5.5 \\
Reforestation around the factory & 85 & 84 & & 8 & 177 & 4.21 & 9 \\
Installation of solar penal on the roof & 110 & 64 & 12 & & & 186 & 4.42 & 3 \\
of the factory & 50 & 52 & 24 & 20 & 1 & 147 & 3.50 & 14 \\
Using the high mileage vehicles & 115 & 60 & 12 & & & 187 & 4.45 & 2 \\
Reducing the sound pollution & 70 & 48 & 36 & & 4 & 158 & 3.76 & 12.5 \\
Video conference instead of physical & & & & & & & & \\
meeting & 95 & 68 & 18 & & & 181 & 4.31 & 7 \\
Water contamination & 80 & 40 & 24 & 12 & 2 & 158 & 3.76 & 12.5 \\
Soil contamination & 100 & 72 & 6 & 4 & & 182 & 4.33 & 5.5 \\
Air pollution & 125 & 48 & 15 & & & 188 & 4.48 & 1 \\
Energy savings & 90 & 80 & 6 & 4 & & 180 & 4.29 & 8 \\
Tree plantations & 75 & 52 & 30 & 4 & 2 & 163 & 3.89 & 11 \\
Production of green products & 90 & 68 & 9 & 4 & 2 & 173 & 4.11 & 10 \\
Reduction of carbon & & & & & & & & \\
\hline
\end{tabular}

Source: Field investigation

The study investigates to explore the management views regarding green business environment before the investment decision. The green investment climate is pre-requisite for green investment. The management should scrutinize 
the environmental factors before an investment decision. The average value of the ranking method is more than 4.0 and a few values are less than 4 . This result proves that Islamic banks are considered the components of investment climates in most cases. The most of respondents agreed that they ensure green environment factors before the investment decision.

Green Investments (finance) implies the financial services to the businesses and projects that help prevent deterioration of the environment as well as which are not harmful to the environment.

Table 7. Management perception on green products towards green investment

\begin{tabular}{lcccccccc}
\hline \multicolumn{1}{c}{ Statements } & $\mathbf{1}$ & $\mathbf{2}$ & $\mathbf{3}$ & $\mathbf{4}$ & $\mathbf{5}$ & Total & Mean & Rank \\
\hline $\begin{array}{l}\text { Projects having zig zag kiln and } \\
\text { tunnel kiln }\end{array}$ & 120 & 60 & 9 & & & 189 & 4.50 & 1 \\
Projects having ETP & 115 & 56 & 9 & 4 & & 184 & 4.38 & 2 \\
Waste and hazards disposal plant & 110 & 52 & 15 & 4 & & 181 & 4.31 & 4 \\
Waste battery recycling plant & 105 & 48 & 15 & 6 & 1 & 175 & 4.17 & 6.5 \\
Waste paper recycling plant & 95 & 52 & 24 & 2 & 1 & 174 & 4.14 & 8.5 \\
PET bottle recycling plant & 100 & 56 & 6 & 6 & 2 & 170 & 4.05 & 11 \\
Solar system & 90 & 72 & 12 & 4 & & 178 & 4.24 & 5 \\
Bio fertilizer plant & 85 & 52 & 30 & 4 & & 171 & 4.07 & 10 \\
Bio gas & 95 & 48 & 27 & 4 & & 174 & 4.14 & 8.5 \\
Energy saving bulbs production & 85 & 64 & 9 & 8 & 2 & 160 & 3.81 & 12 \\
plant & 95 & 60 & 12 & 8 & & 175 & 4.17 & 6.5 \\
Clean water supply projects & 115 & 48 & 15 & 4 & & 182 & 4.33 & 3 \\
Green loans & 50 & 44 & 27 & 20 & 2 & 143 & 3.40 & 13 \\
others & & & & & &
\end{tabular}

Source: Field investigation

The study was conducted to explore the management views on various green products regarding investment. The study tests the investment premises of Islamic banks in Bangladesh and found that most of the Islamic banks made their investment in green products. The results of the survey explored the score more than 4 and less than 4. It is clear that Islamic banks attempted to invest their funds in green products and services. The findings of this study are significant which exceed the average score. 
Table 8. Investor's Perception Towards Green Conception for Green Investment

\begin{tabular}{lcc}
\hline \multicolumn{1}{c}{ Statements } & \multicolumn{2}{c}{ Response } \\
& Yes & No \\
\hline Have you heard the concept of green? & $100 \%$ & $0 \%$ \\
Do you like the green society? & $97 \%$ & $3 \%$ \\
Do you think going green is costly? & $14 \%$ & $86 \%$ \\
Are you aware about environmental risk? & $87 \%$ & $13 \%$ \\
Green society is related to sustainable development? & $91 \%$ & $9 \%$ \\
\hline
\end{tabular}

(Note: Percentage exceeds 100 because respondents mentioned more than one factor)

Source: Field investigation.

The questions in Table 8 were presented to the investors of Islamic banking to identify the green awareness in the investment arena. The study places these issues to explore the green message from the investors. These questions are essential if the investors not introduced and realized with the green concept then they would not feel cordial to execute the green investment. The study provided very significant result in this regard because most of the investors are interested in green investment.

Table 9. Terms and conditions of green financing contract to investors

\begin{tabular}{ccc}
\hline Statements & Frequency & Percentage \\
\hline Shari'ah compliance & 84 & $100 \%$ \\
Environmental compliance & 84 & $100 \%$ \\
Green Mortgage & 78 & $93 \%$ \\
Cost of finance & 70 & $83 \%$ \\
Duration of investment & n.a. & n.a. \\
\hline
\end{tabular}

(Note: Percentage exceeds 100 because respondents mentioned more than one factor)

The questions were asked to investors to take into consideration which aspects of investment given preference in providing investment to investors. 100 percent of respondents agreed that bank provides investment to ensure the 'Sharia's' compliance and protection of the environment during the investment period. 93 percent of respondents opined that banks inspect the green mortgage that provides the security of investment and protect the environment also. 83 percent of respondents appeared that Islamic banks consider the cost of financing in giving the investment. 
Table 10. Investor's Perception Towards Environmental Factors of Investment in Bangladesh

\begin{tabular}{lcccccccc}
\hline Statements & $\mathbf{1}$ & $\mathbf{2}$ & $\mathbf{3}$ & $\mathbf{4}$ & $\mathbf{5}$ & Total & Mean & Rank \\
\hline $\begin{array}{l}\text { Cleaning and hygienic business } \\
\text { environment }\end{array}$ & 300 & 60 & 15 & 8 & 383 & 4.56 & 1 \\
Green factory buildings & 250 & 80 & 30 & 8 & 368 & 4.38 & 3 \\
Reforestation around the factory & 285 & 68 & 15 & 10 & 378 & 4.50 & 2 \\
Installation of solar penal on the & 245 & 84 & 21 & 14 & & 364 & 4.33 & 4.5 \\
roof of the factory & 150 & 94 & 75 & 10 & & 329 & 3.92 & 12 \\
Using the high mileage vehicles & 205 & 56 & 72 & 8 & 1 & 342 & 4.07 & 10 \\
Reducing the sound pollution & 240 & 64 & 48 & 8 & & 360 & 4.29 & 6 \\
Water contamination & 215 & 72 & 57 & 4 & 2 & 350 & 4.17 & 8 \\
Soil contamination & 160 & 88 & 60 & 20 & & 328 & 3.90 & 13 \\
Air pollution & 240 & 72 & 30 & 16 & & 358 & 4.26 & 7 \\
Energy savings & 245 & 76 & 33 & 10 & & 364 & 4.33 & 4.5 \\
Tree plantations & 190 & 104 & 45 & 10 & & 349 & 4.15 & 9 \\
Production of green products & 155 & 84 & 51 & 44 & 4 & 338 & 4.02 & 11 \\
Reduction of carbon & & & & & & &
\end{tabular}

Source: Field investigation.

The study investigates to explore the investor's views regarding the green business environment in the business premises. Green banking provides a foundation of environmental protection that would be protected by Islamic banks through investment. It is evident from the study that Islamic banks conducted investment activities ensuring the environmental act. The result proved that Islamic banks provided investment considering the environmental factors. The mean score of each element is more than one, which confirmed that the effect is significant.

The study was conducted to explore the investor's views on various green products regarding investment. All sharia's based banks invested in green investment products and services, which found from above study. The average score of investments is higher than 4.0, and only two scores are less than 4.0. The results prove that Islamic banks carried out investment activities with environment protection maintaining the sharia's compliance. 
Table 11. Investor's Perception on Various Types of Green Investment

\begin{tabular}{lllllllll}
\hline Statements & 1 & 2 & 3 & 4 & 5 & Total & Mean & Rank \\
\hline Projects having zig zag kiln and tunnel kiln & 255 & 60 & 42 & 8 & & 365 & 4.35 & 6.5 \\
Projects having ETP & 290 & 56 & 27 & 6 & 379 & 4.51 & 1 \\
Effluent treatment plant & 275 & 72 & 21 & 8 & & 376 & 4.47 & 2 \\
Waste battery recycling plant & 255 & 68 & 36 & 6 & 1 & 366 & 4.35 & 6.5 \\
Waste management projects & 280 & 64 & 24 & 4 & 2 & 374 & 4.45 & 3 \\
Solar/Renewable energy plant & 270 & 84 & & 10 & 4 & 368 & 4.38 & 4.5 \\
Bio fertilizer plant & 245 & 92 & 12 & 16 & & 365 & 4.34 & 8 \\
Bio gas plant & 225 & 80 & 48 & 6 & & 359 & 4.27 & 9 \\
Energy saving bulbs production plant & 275 & 52 & 27 & 14 & & 368 & 4.38 & 4.5 \\
Clean water supply projects & 190 & 84 & 66 & 6 & & 346 & 4.12 & 11 \\
Carbon credit business (CDM) & 115 & 96 & 102 & 6 & & 319 & 3.80 & 13 \\
Production of green products & 220 & 104 & 15 & 10 & 4 & 353 & 4.20 & 10 \\
Green credit card & 190 & 76 & 45 & 24 & & 335 & 3.98 & 12 \\
\hline
\end{tabular}

\section{Conclusion}

Green banking as part of Islamic banking can play a pro-active role in emerging economy for sustainable development. The trend of Islamic banking has been growing in Bangladesh, which is an aid to environmental protection as well as sustainable development. Social structure is significantly changing day to day due to unplanned city building, deforestation, digging hill tracts, natural disaster, and deregulation. These factors have been increasing pressures on the ecosystem of a country that significantly impedes the sustainable development. Banks should be strict for compliance with environmental protection norms by the borrowers so that environment can remain in sustainable state and civilization is free from environmental threats.

The study aims at providing the relationship between Islamic banking and green banking for sustainable development in Bangladesh. From the study, it found that Islamic banks prefer green banking as a compliance of 'Shari'ah'. Furthermore, green banking has more significant connection to the Islamic Islamic as it supports the features- social responsibility, cleanliness, reduce wastage of resources and uphold ethics- of green banking (Masukujjaman, 2016). The study provides the evidence that Islamic banks are significantly following the components of green banking. Most of the respondents are satisfied with the current green banking and revealed that green banking is conducive to the Islamic banking. It is evident that there are main obstacles for green banking practices are awareness, knowledge deficiency, and green risk, etc. The study provides concrete suggestions based on opinions of respondents that Islamic banking should practice green banking in- 
house and out to protect the environment for sustainable development.

In considering the opinions of respondents, the following measures recommended to stakeholders of the study: First, Bangladesh Bank should take the initiative to mandate the scheduled banks to provide full-fledged green banking services to their customers for sustainable development. Second, Islamic banks should increase the awareness of green banking to the officials and customers through seminar, symposium and training programs. Third, Bangladesh bank should arrange Diploma, training programs and short courses on green banking to provide the knowledge on green banking to the officials of scheduled banks.

\section{References}

Biswas, N. (2011). Sustainable Green Banking Approach: The Need of the Hours. Business Spectrum. 1 (1): 32-38.

Bangladesh Bank Green Banking Policy Guideline. (2013). Green Banking and CSR Department. Dhaka: Bangladesh Bank

Bhardwaj B.R., \& A. Malhotra. (2013) Green Banking Strategies: Sustainability through Corporate Entrepreneurship. Greener Journal of Business and Management Studies. 3 (4): 180-193,

Bihari, S.C. (2011) Green Banking towards Socially Responsible Banking in India. International Journal of Business Inshights and Transformation. 4(1): 82-87.

Choudhury, T.T., Md. Salim., Md.M. Al Bashir., \& P. Saha. (2013). Influence of Stakeholders in Developing Green Banking Products in Bangladesh. Research Journal of Finance and Accounting. 4 (7): 67-77.

Cerin, P. (2006). Bringing Economic Opportunity into line with Environmental Influence: A Discussion on the Cease theorem and the Porter and van der Linde Hypothesis. Ecological Economics. 56: 209-225.

Dernbach, J. C. (1998). Sustainable Development as a Framework for National Governance. Case Western Reserve Law Review. 49 (1): 1-103.

Habib, S.M.A., M.S. Ullah., T. Rahman., A. Zareen., \& N. Faisal. (2014). Development of Green Banking in Bangladesh: Status and Prospects in Green Banking in Bangladesh. Environmental Risk Management in Banking. Dhaka: Bangladesh Institute of Bank Management (BIBM).

Goyal, K.A, \& V. Joshi. (2011). A Study of Social and Ethical Issues In Banking Industry. International Journal of Economics and Research. 2 (5): 49-57.

Islam, M.S. \& P.C. Das. (2013). Green Banking Practices in Bangladesh. Journal of Business Management. 8 (3): 39-44.

Islam M.T., I.K. Abdullah., \& A. Farzana. (2013). Green banking in Bangladesh: Synchronous Metamorphosis in Banking Action" Research Journal of Economics and Business Studies. 3 (1): 53-62. 
Lalon R. M. (2015). Green Banking: Going Green. International Journal of Economics, Finance and Management Sciences. 3 (1): 34-42.

Masukujjaman, M., Md.R. Mahmud., S. Chamhuri., \& S.S. Alam. (2016). Bankers' Perception of Green Banking: Learning from the Experience of Islamic Banks in Bangladesh. Malaysian Journal of Society and Space. 12 (2): 144-153. Masukujjaman, M., \& S. Aktar. (2014). Green Banking in Bangladesh: A Commitment towards the Global Initiatives. Journal of Business and Technology. 8 (1-2): 17- 40.

Mutahhari M.A. (2014). Man and the Holy Qur'an. Man and Universe. Chapter 22. [Cited 27/1/2015]. Available from: http://www.najaf.org/english/ book/19/22.ht.

Millat, K.M., R. Chowdhury., \& E.A. Singha. (2012). Green Banking in Bangladesh Fostering Environmentally Sustainable Inclusive Growth Process. Dhaka: Bangladesh Bank.

N.A.H.H. Nuruddin. (2012). Islam and the Go Green Concept. The Star Online. Retrieved from http://www.thestar.com.my/story.aspx/?file=\%2f2012\%2f11 $\% 2 \mathrm{f} 6 \% 2$ ffocus $\% 2 \mathrm{f} 12262871 \& \mathrm{sec}=$ focus

Rahman, S.M.M., \& S. Barua. (2016). The Design and Adoption of Green Banking Framework for Environment Protection: Lessons from Bangladesh. Australian Journal of Sustainable Business and Society. 2 (1): 1-19.

Sahoo P, \& B.P. Nayak. (2007). Green banking in India. Indian Economic Journal. 55(3): 82-98.

Shaumya, K. \& A. Arulrajah. (2017). The Impact of Green Banking Pratices on Bank's Performance: Evidence from Sri Lanka. Journal of Finance and Bank Management. 5 (1): 77-90. doi: 10.15640/jfbm.v5n1a7.

Tara, K., S. Singn., \& R. Kumar. (2015). Green Banking for Environmental Management: A Paradigm Shift. Current World Environment. 10 (3): 1029-1038.

United Nations General Assembly. (1987). Report of the World Commission on Environment and Development: Our Common Future. Oslo, Norway: United Nations General Assembly, Development and International Co-operation: Environment.

UNEP. (2011). UNEP FI Guide to Banking \& Sustainability. United Nations Environment Programme, Geneva, www.unepfi.org/

Ullah, M. M. (2013). Green Banking in Bangladesh-A Comparative Analysis. World Review Of Business Research. 3 (4): 74-83.

Uddin, M.N. (2016). Shari'ah Based Banking and Green Financing: Evidence from Bangladesh. Journal of Emerging Economies' and Islamic Research. 4(2): 50-62. 